\title{
Fine particulate matter aggravates allergic airway inflammation through thymic stromal lymphopoietin activation in mice
}

\author{
YAN LIU ${ }^{1}$, GAN-ZHU FENG ${ }^{2}$, QIANG DU ${ }^{2}$, XIAO-XIANG JIN ${ }^{1}$ and XING-RAN DU ${ }^{2}$ \\ ${ }^{1}$ Department of Respiratory, The Central Hospital of Maanshan, Maanshan, Anhui 243000; \\ ${ }^{2}$ Department of Respiratory Medicine, The Second Affiliated Hospital of Nanjing Medical University, \\ Nanjing, Jiangsu 210011, P.R. China
}

Received July 11, 2016; Accepted April 25, 2017

DOI: $10.3892 / \mathrm{mmr} .2017 .7089$

\begin{abstract}
Fine particulate matter (PM2.5) has been linked to exacerbation of allergic airway inflammation in mice. However, the mechanism underlying exposure to PM2.5 and subsequent and adverse effects remains to be fully elucidated. Therefore, the present study aimed to investigate the effects of PM2.5 by different levels on airway inflammation in mouse models of in allergic and steroid-resistant asthma. BALB/c mice were nasally instilled with PBS (control) or 10, 31.6 or $100 \mu \mathrm{g}$ PM2.5, and randomly assigned into nine groups. The acute asthma model was previously induced to investigate the change of inflammatory cells in bronchoalveolar lavage fluid (BALF). Histopathological changes of the lung were assessed, in addition to levels of interleukin (IL)-4 and IL-13 in BALF and immunoglobulin Ein serum. Thymic stromal lymphopoietin (TSLP) proteinexpression levels were assessed by western blotting. The present study demonstrated that medium- and high-dose PM2.5 is linked to acute exacerbation of allergic airway inflammation in mice. In conclusion, the pathological mechanisms of PM2.5 may be associated with allergic/steroid-resistant airway inflammation, T-cell helper (Th)1/Th2 cytokine production and upregulation of TSLP expression in a murine model of allergic and steroid-resistant asthma.
\end{abstract}

\section{Introduction}

Asthma is a respiratory disease that has been reported to represent a significant threat to human health, especially for children. In 2006, the Global Initiative for Asthma noted that

Correspondence to: Dr Gan-Zhu Feng or Dr Qiang Du, Department of Respiratory Medicine, The Second Affiliated Hospital of Nanjing Medical University, 121 Jiangjiayuan Road, Nanjing, Jiangsu 210011, P.R. China

E-mail: zhu1635253@163.com

E-mail: jingshuyue@163.com

Key words: fine particulate matter, interleukin-4, interleukin-13, immunoglobulin E, thymic stromal lymphopoietin asthma is a heterogeneous disease that is usually characterized by chronic airway inflammation (1). However, the complex mechanisms involved in the induction of a Th2-biased immunologic response remain to be fully elucidated. An important molecular mechanism involved in asthma is type 2 inflammation (2,3). Type 2 helper T cells release cytokines, including interleukin (IL)-4 and IL-13. They also activate $\mathrm{B}$ cells, and promote immunoglobulin $\mathrm{E}$ ( $\mathrm{IgE}$ ) expression, recruitment of mast cells and eosinophilia. Environmental factors have been implicated to serve important roles in the mechanism of asthma. Anumber of studies have demonstrated that exposure to ambient particulate matter is linked to acute exacerbations of asthma (4,5). To investigate the effects of fine particulate matter (PM2.5) at different dosages on airway inflammationin a mouse model of asthma, the present study generated a successful model of acute allergic asthma in mice by nasally instilling PM2.5 at different dosages (10, 31.6 or $100 \mu \mathrm{g})$. Glucocorticoids were intraperitoneally injected into the ovalbumin (OVA)-induced allergic mice that had been exposed to PM2.5 at three different dosages. To the best of our knowledge, the present study evaluated for the first time the effects of PM2.5 on various parameters of the allergic airway inflammation in these mouse models. Gavett et al (6) demonstrated that inhalation of three different concentrations $\left(42,134\right.$, or $\left.425 \mu \mathrm{g} / \mathrm{m}^{3}\right)$ PM2.5 would produce human doses per tracheobronchial surface area equivalent to aspiration by mice of doses $(10,31.6$ or $100 \mu \mathrm{g})$, respectively. Furthermore, the mouse-aspirated doses $(10,31.6$ or $100 \mu \mathrm{g})$ in turn were equivalent to good, moderate and severe pollution, referring to a correlation chart consisting of PM2.5 standards, air quality index and air quality level. The chart was established by the US. Environmental Protection Agency in 2006 (7).

\section{Materials and methods}

Source of PM2.5. PM2.5 was collected with an Anderson-type high volume sampler (Wuhan Tianhong TH-150) at a moderate rate. This flow rate was aerodynamically calculated to obtain PM2.5 with a diameter of $\leq 2.5 \mu \mathrm{m}$. The fine particulate matter was stored in a freezer at $-20^{\circ} \mathrm{C}$ until further required.

Animals. Female BALB/c mice (age, 8 weeks; n=70) were obtained from the Nanjing Medical University Experimental 
Animal Center (Nanjing, China). Animals (weight, 20-25 g) were held individually in ventilated cages, exposed to a 12-h light/dark cycle and were given free access to food and water under standard laboratory conditions of $22-28^{\circ} \mathrm{C}$ and relative humidity of 50-60\%. The care and handling of the animals were in accordance with a protocol approved by the Institutional Animal Care and Use Committee of the Nanjing Medical University, and the experimental protocol was approved by the institutional animal ethics group.

Experimental groups. The BALB/c mice were randomly divided into nine groups: Control $(n=6)$, OVA $(n=8)$, OVA/dexamethasone (DXM; n=8), OVA/PM2.5 (10 $\mu \mathrm{g}$; $\mathrm{n}=8)$, OVA/PM2.5 (31.6 $\mu \mathrm{g} ; \mathrm{n}=8)$, OVA/PM2.5 $(100 \mu \mathrm{g} ; \mathrm{n}=8)$, OVA/DXM/PM2.5 (10 $\mu \mathrm{g} ; \mathrm{n}=8)$, OVA/DXM/PM2.5 (31.6 $\mu \mathrm{g}$; $\mathrm{n}=8)$ and OVA/DXM/PM2.5 (100 $\mu \mathrm{g} ; \mathrm{n}=8)$.To establish the model of asthma, 64 mice were sensitizedby intraperitoneal injections of $20 \mu \mathrm{g}$ OVA (Grade V; Sigma-Aldrich; Merck $\mathrm{KGaA}$, Darmstadt, Germany) emulsified in $2.25 \mathrm{mg}$ aluminum hydroxide in a total volume of $0.1 \mathrm{ml}$ and challenged with aerosol inhalation of $1 \%$ OVA for 30 min daily for 5 consecutive days. In addition, mice were nasally instilled with PBS (control) or 10,31.6 or $100 \mu \mathrm{g}$ PM2.5, and DXM was intraperitoneally injected into the OVA induced allergic mice that were exposed to PM2.5 at the three different dosages.

Analysis of bronchoalveolar lavage fluid (BALF) and total $I g E$ in serum. Each mouse was anaesthetised with an intraperitoneal injection of $1 \%$ sodium pentobarbital (200 $\mu 1 /$ mouse), and a sample of blood $(1 \mathrm{ml})$ was collected via retroorbital puncture using heparinized capillary tubes. Blood samples were centrifuged $\left(2,000 \mathrm{xg}\right.$ for $10 \mathrm{~min}$ at $\left.4^{\circ} \mathrm{C}\right)$, and the plasma was stored at $-70^{\circ} \mathrm{C}$. The BALF was centrifuged $(1,500 \times \mathrm{g}$ for $10 \mathrm{~min}$ at $4^{\circ} \mathrm{C}$ ) and washed twice with $0.5 \mathrm{ml}$ saline. Differential cell counts were performed with Wright's staining (for $10 \mathrm{~min}$ at room temperature) following centrifugation, $\geq 200$ cells were counted for each sample. The expression levels of IL-4 (cat. no. JEM-03; Shanghai Joyee Biotechnics Co. Ltd., Shanghai, China) and IL-13 (cat. no. BMS6015; eBioscience; Thermo Fisher Scientific, Inc., Waltham, MA, USA) in BALF and total IgE (cat. no. CSB-E07983m; Cusabio Biotech Co. Ltd., Wuhan China) in serum were measured by ELISA according to the manufacturer's protocol.

Histological experiments. The mice were sacrificed and the left lungs were removed (8), immersed in $4 \%$ formaldehyde overnight, and subsequently embedded in paraffin and sections. Sections $(5-6 \mu \mathrm{m})$ were stained with haematoxylin-eosin (30 min at room temperature). An image-analysis system (Image-Pro Plus; Media Cybernetics, Inc., Rockville, MD, USA) was used to analyze the lung histopathology. The severity of the inflammatory cell infiltration was blindly assessed using a 5-point scoring system (9). The scoring system was: 0 , no cells; 1 , a few cells; 2 , a ring of cells 1 cell layer deep; 3 , a ring of cells $2-4$ cells deep and 4 , a ring of cells 4 cells deep.

Western blot analysis. The right lung tissues from the nine groups were added to $1 \mathrm{ml}$ radioimmunoprecipitation assay lysis buffer (Wuhan Sevicebio Technology Co., Ltd., Wuhan, China) supplemented with $20 \mu 1$ cocktail phosphatase inhibitors, $2 \mu \mathrm{l}$ protease inhibitors and $10 \mu \mathrm{l}$ $100 \mathrm{mM}$ phenylmethanesulfonylfluoride, Tissue samples were lysed on ice and oscillated at $4^{\circ} \mathrm{C}$ for $30 \mathrm{~min}$. Following lysis, the resulting supernatants were collected as total protein samples by centrifugation at $12,000 \mathrm{x}$ g for $15 \mathrm{~min}$ at $4^{\circ} \mathrm{C}$, and protein concentrations were determined using the Bicinchoninic Acid protein assay. Equal amounts of protein extracts $(20 \mu \mathrm{g})$ were separated by $10 \%$ SDS-PAGE and blotted onto polyvinylidene difluoride membranes (EMD Millipore, Billerica, MA, USA). The membrane was subsequently blocked in blocking solution (5\% non-fat milk, $10 \mathrm{mM}$ Tris- $\mathrm{HCl}, 150 \mathrm{mM} \mathrm{NaCl}$, $0.05 \%$ Tween-20) at room temperature for $1 \mathrm{~h}$ and incubated with the following primary antibodies: Anti-actin (1:3,000 dilution, cat. no. sc-1616r; Santa Cruz Biotechnology, Inc., Dallas, TX, USA) and anti-TSLP (1:3,000 dilution, cat. no. ab188766; Abcam, Cambridge, MA, USA) polyclonal primary antibodies overnight at $4^{\circ} \mathrm{C}$, Membranes were washed with $10 \mathrm{mM}$ Tris- $\mathrm{HCl}, 150 \mathrm{mM} \mathrm{NaCl}$ and $0.05 \%$ Tween-20 (TBST) three times, for $5 \mathrm{~min}$ per wash. The membranes were incubated with the HRP-conjugated goat anti-rabbit IgG antibody (1:5,000 dilution, cat no. sc-2004; Santa Cruz Biotechnology, Inc.) at room temperature for $30 \mathrm{~min}$. The membranes were then washed with TBST three times, for 5 min per wash (10). Densitometric analysis was performed using Image J software $1.47 \mathrm{v}$ (National Institutes of Health, Bethesda, MD, USA) after the scanning of the Kodak X-Omat LS X-ray films.

Statistical analysis. Data are expressed as the mean \pm standard error, and were analysed by one-way analysis of variance followed by the least significant difference post hoc test. SPSS software version 20 (IBM Corp., Armonk, NY, USA) was used for data analysis. $\mathrm{P}<0.05$ was considered to indicate a statistically significant difference.

\section{Results}

Effect of PM2.5 on histopathological changes in the lungs. Compared with the lack of inflammation in the control group, a significant increase in the infiltration of inflammatory cells and bronchial wall thickening were observed in the OVA and OVA/PM2.5 $(10,31.6$ and $100 \mu \mathrm{g})$ groups. The vast majority of the inflammatory cell infiltration resulted from a marked eosinophilia and a significant enhancement in the number of lymphocytes and neutrophils. In contrast, the inflammatory scores of the peribronchial and perivascular regions were significantly reduced in the OVA/DXM/PM2.5 (10, 31.6 and $100 \mu \mathrm{g}$ ) groups, compared with those in the OVA group (Fig. 1A). Furthermore, the statistical significance of the differences in the inflammatory scores in the OVA/DXM/PM2.5 $(10,31.6$ and $100 \mu \mathrm{g})$ groups compared with those in the OVA group decreased with exposure levels $(\mathrm{P}=0.004, \mathrm{P}=0.015$ and $\mathrm{P}=0.04$, respectively; Fig. 1B).

PM2.5 promotes asthmatic airway inflammation. In preliminary experiments, the control and glucocorticoid therapy group did not exhibit evidence of airway inflammation in terms of the total number of cells in BALF [the total cell counts in the control group, OVA/DXM group, OVA/DXM/PM2.5 $(10 \mu \mathrm{g})$ group, OVA/DXM/PM2.5 $(31.6 \mu \mathrm{g})$ group and OVA/DXM/PM2.5 $(100 \mu \mathrm{g})$ group are $35.8 \pm 5.8 \times 10^{4}, 56 \pm 15.1 \times 10^{4}, 49.8 \pm 13.6 \times 10^{4}$, 

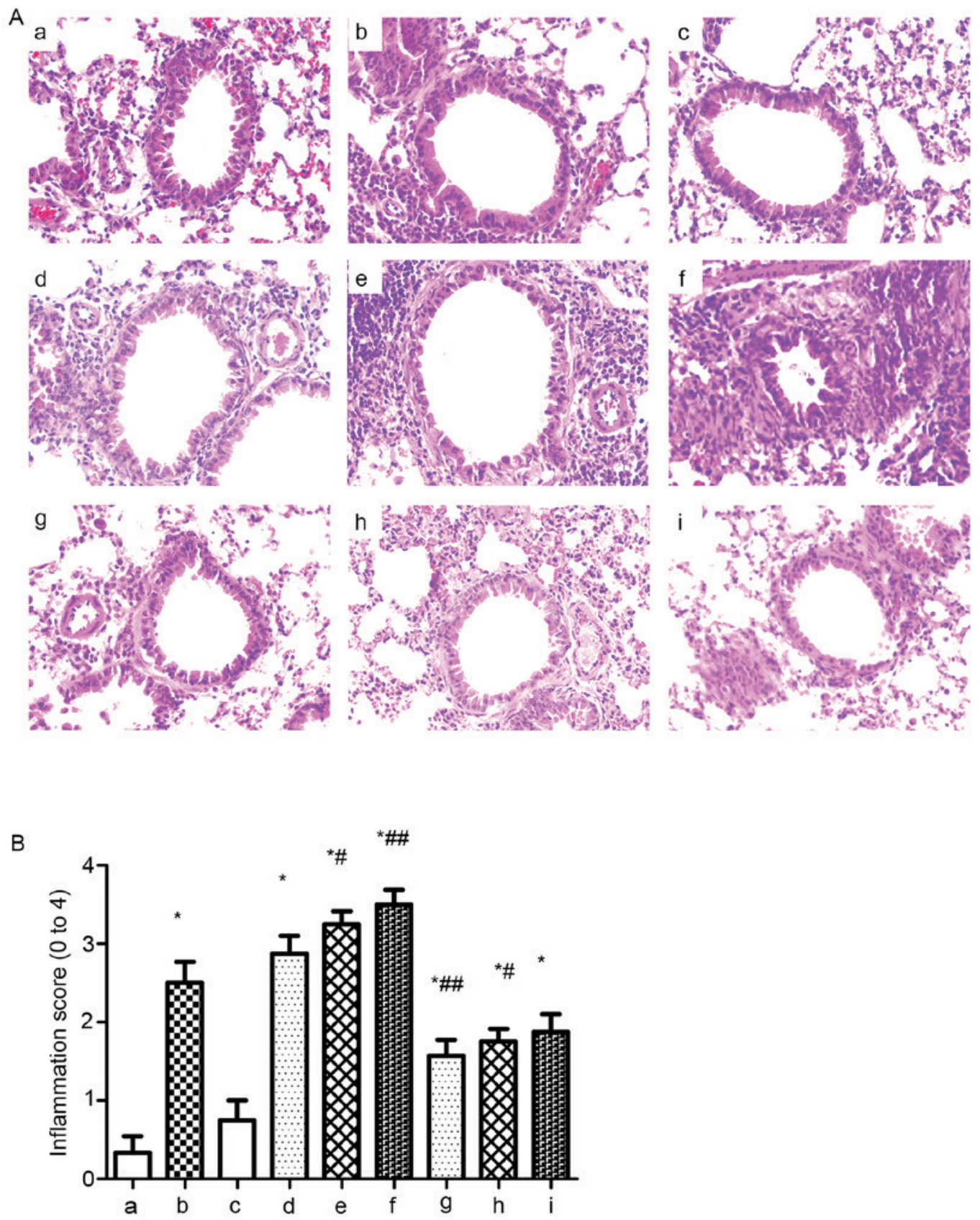

Figure 1. Effects of PM2.5 on the infiltration of inflammatory cells in allergic asthma and steroid-resistant asthma. (A) Hematoxylin and eosin staining of lung tissues from each group. (magnification, $\mathrm{x} 400$ ). (B) Lung inflammation scores. Data are expressed as the mean \pm standard error $\left(\mathrm{n}=6-8 /\right.$ group). ${ }^{*} \mathrm{P}<0.05$ vs. control group; ${ }^{\#} \mathrm{P}<0.05$ and ${ }^{\# \#} \mathrm{P}<0.01$ vs. OVA group. a, control group; b, OVA group; c, OVA/DXM group; d, OVA/PM2.5 (10 $\left.\mu \mathrm{g}\right)$ group; e, OVA/PM2.5 $(31.6 \mu \mathrm{g})$ group; f, OVA/PM2.5 (100 $\mu \mathrm{g})$ group; g, OVA/DXM/PM2.5 (10 $\mu \mathrm{g})$ group; h, OVA/DXM/PM2.5 (31.6 $\mu \mathrm{g})$ group; i, OVA/DXM/PM2.5 (100 $\mu \mathrm{g})$ group. OVA, ovalbumin; DXM, dexamethasone; PM2.5, fine particulate matter.

$\left.56 \pm 8.4 \times 10^{4}, 62.6 \pm 7.4 \times 10^{4}\right]$. The number of total inflammatory cell in the OVA/DXM/PM2.5 (10 and $31.6 \mu \mathrm{g})$ group was significantly reduced compared with the OVA group $(\mathrm{P}<0.05)$, while there were no significant differences between the OVA/DXM/PM2.5 $(100 \mu \mathrm{g})$ and OVA groups $(\mathrm{P}>0.05$, Fig. 2A). Importantly, there was a significant increase in the percentage of eosinophils in all OVA/PM2.5 groups (11.3 \pm 3.6 , $13.6 \pm 1.8$ and $16.1 \pm 2.4)$ compared with the OVA group (10.5 \pm 1.6 , Fig. 2B). The percentage of neutrophils in the BALF was also significantly increased in the OVA/PM2.5 groups $(11.3 \pm 3.6,13.6 \pm 1.8$ and $16.1 \pm 2.4)$ compared with the OVA group (7.6 \pm 0.5$)$. Furthermore, the percentage of neutrophils in the OVA/DXM/PM2.5 $(100 \mu \mathrm{g})$ group was significantly increased compared with the OVA/DXM group (Fig. 2C). The percentage of lymphocytes in the BALF was similarly increased (Fig. 2D) and that of the macrophages was correspondingly decreased in the OVA/PM2.5 groups (10, 31.6 and $100 \mu \mathrm{g}$ ) compared with the OVA group (Fig. 2E).

Effect of PM2.5 on the expression of IL-4 and IL-13 in the $B A L F$ and total $\operatorname{IgE}$ in serum. In the OVA group, the levels of the T-helper 2 (Th2) cell cytokines IL-4 (78.1 $\pm 9.9 \mathrm{pg} / \mathrm{ml})$ in 

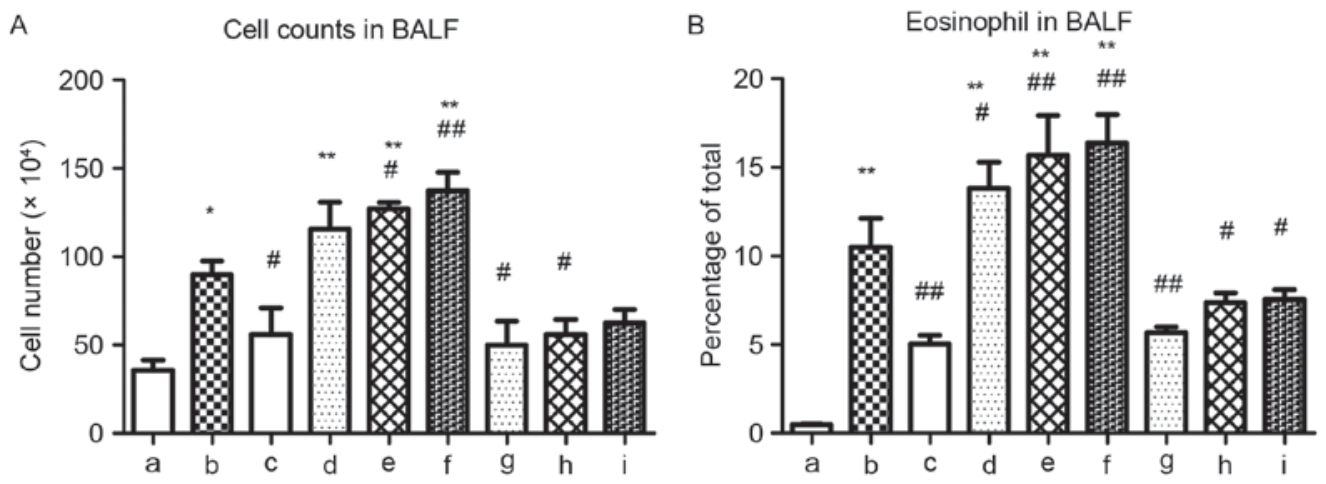

C

D

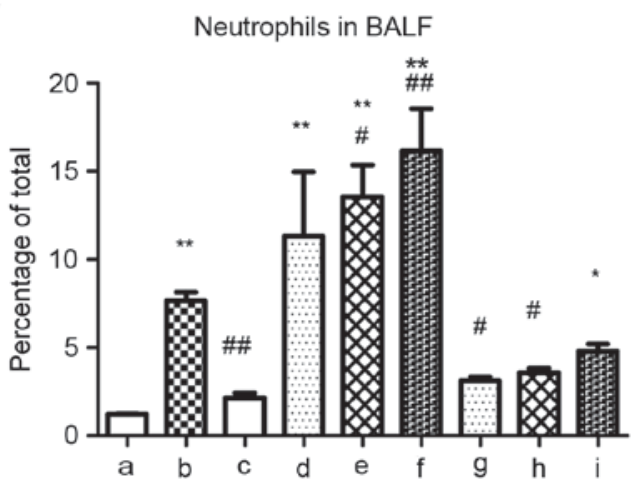

Lymphocytes in BALF
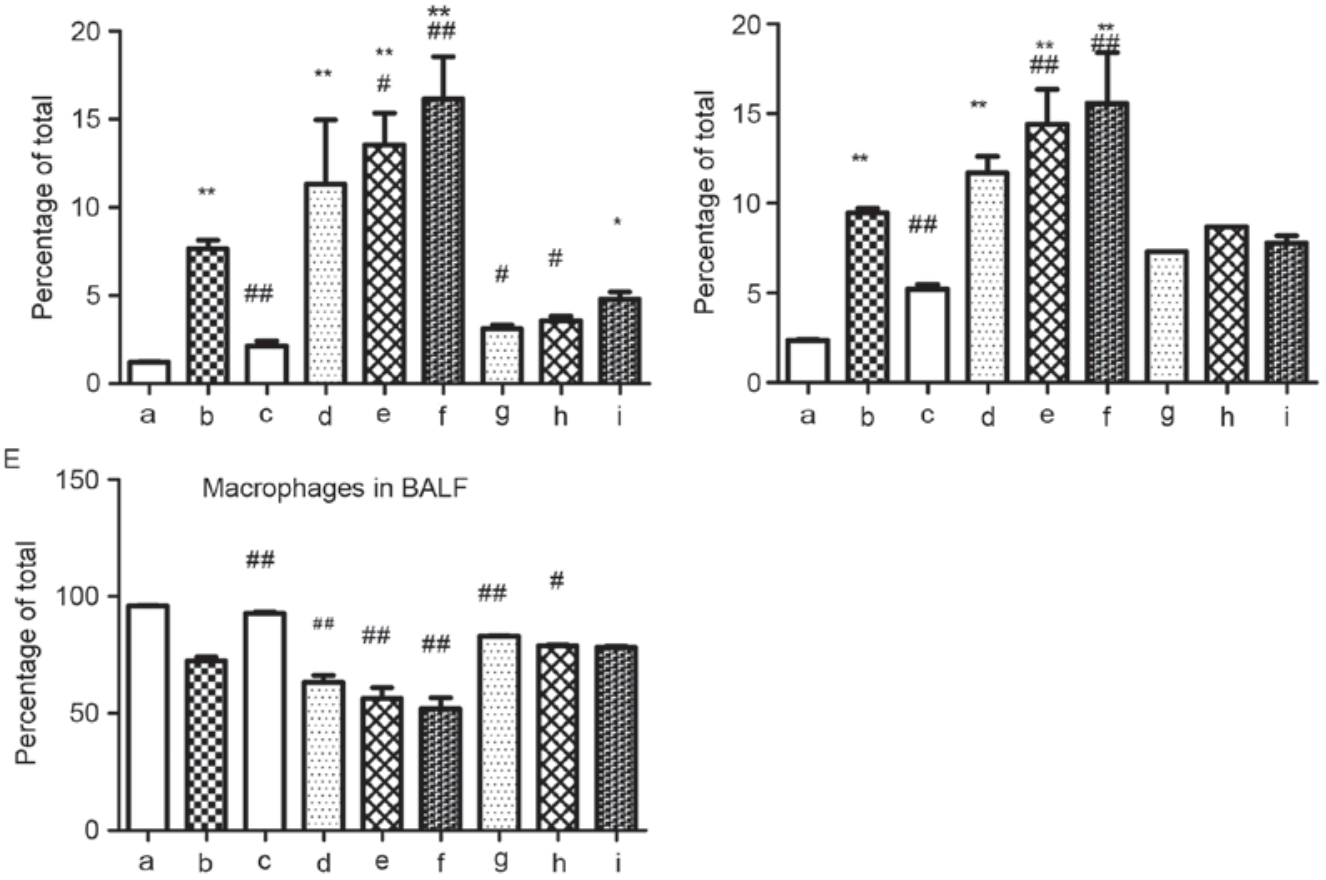

Figure 2. Inflammatory cell accumulation in BALF in a murine model of asthma. (A) Cell counts and levels of (B) eosinophil, (C) neutrophils, (D) lymphocytes and (E) macrophages. Data are expressed as the mean \pm standard error ( $\mathrm{n}=6-8$ /group). ${ }^{*} \mathrm{P}<0.05$ and ${ }^{* *} \mathrm{P}<0.01$ vs. control group; ${ }^{\#} \mathrm{P}<0.05$ and ${ }^{\# \#} \mathrm{P}<0.01$ vs. OVA group. a, control group; b, OVA group; c, OVA/DXM group; d, OVA/PM2.5 (10 $\mu \mathrm{g})$ group; e, OVA/PM2.5 (31.6 $\mu \mathrm{g})$ group; f, OVA/PM2.5 (100 $\mu \mathrm{g})$ group; g, OVA/DXM/PM2.5 (10 $\mu \mathrm{g})$ group; h, OVA/DXM/PM2.5 (31.6 $\mu \mathrm{g})$ group; i, OVA/DXM/PM2.5 (100 $\mu \mathrm{g})$ group. BALF, broncho-alveolar lavage fluid; OVA, ovalbumin; DXM, dexamethasone.

BALF, IL-13 $(21.5 \pm 0.6 \mathrm{pg} / \mathrm{ml})$ in the BALF and total $\mathrm{IgE}$ in serum $(16.8 \pm 2.6 \mathrm{ng} / \mathrm{ml})$ were significantly increased compared with that in the control group $(78.1 \pm 9.9$ vs. $26.9 \pm 1.3 \mathrm{pg} / \mathrm{ml}$, $21.5 \pm 0.6$ vs. $9.8 \pm 0.5 \mathrm{pg} / \mathrm{ml}$ and $16.8 \pm 2.6$ vs. $1.3 \pm 0.5 \mathrm{ng} / \mathrm{ml}$; Fig. 3A-C, respectively). IL-4 levels in the OVA/PM2.5 (100 $\mu \mathrm{g})$ group were significantly increased compared with the OVA group $(98.8 \pm 4.9$ vs. $78.1 \pm 9.9 \mathrm{pg} / \mathrm{ml}$; $\mathrm{P}<0.05$; Fig. $3 \mathrm{~A})$. Levels of IL-13 $(27.9 \pm 1.3 \mathrm{pg} / \mathrm{ml})$ in the BALF and $\operatorname{IgE}(24.2 \pm 3.0 \mathrm{ng} / \mathrm{ml})$ in the serumwere significantly increased in the OVA/PM2.5 $(31.6 \mu \mathrm{g})$ group compared with the OVA group (Fig. 3B-C, $\mathrm{P}<0.05)$. Furthermore, the levels of $\operatorname{IgE}(26.9 \pm 6.9 \mathrm{ng} / \mathrm{ml})$ and IL-13 $(34.5 \pm 2.6 \mathrm{pg} / \mathrm{ml})$ in the OVA/PM2.5 (100 $\mu \mathrm{g})$ group were significantly increased compared with that in the OVA group $(\mathrm{P}<0.01)$. However, the levels of IL-4, IL-13 and IgE in glucocorticoid-treatedasthmatic mice exposed to 10 and $31.6 \mu$ g concentration PM2.5 were not statistically different from the OVA/DXM group. However, those of the glucocorticoid-treatedasthmatic mice exposed to $100 \mu \mathrm{g}$ PM2.5 were revealed to be increased compared with the OVA/DXM group $(\mathrm{P}<0.05)$.

Effect of PM2.5 on the protein expression levels of TSLP. As presented in Fig. 4, Compared with the OVA groups, TSLP protein expression levels were upregulated in mice exposed to PM2.5 in a dose-dependent manner. TSLP expression levels were also upregulated in the OVA/DXM/PM2.5 $(100 \mu \mathrm{g})$ group compared with that in the OVA groups (Fig. 4, $\mathrm{P}<0.05$ ).

\section{Discussion}

The chemical composition of PM2.5 mainly consists of various types of the polycyclic aromatic hydrocarbons (PAHs; including phenanthrene, fluoranthene, naphthalene and acenaphthylene), sodium and other metallic elements (iron and zinc) $(11,12)$. Of these chemical constituents, the PAHs and metallic elements may be associated not only 
A

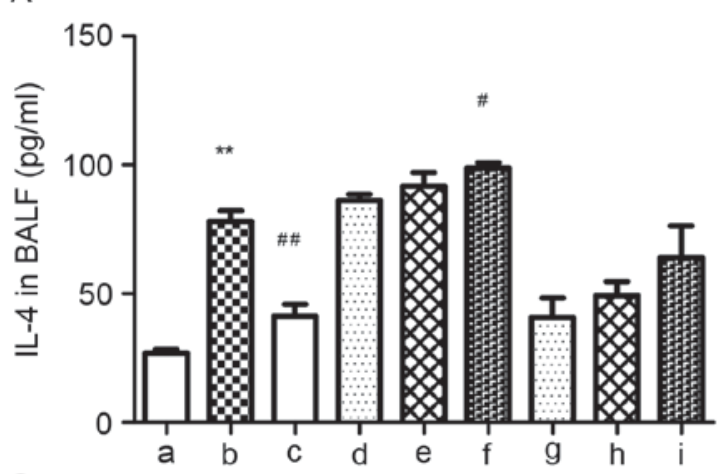

C

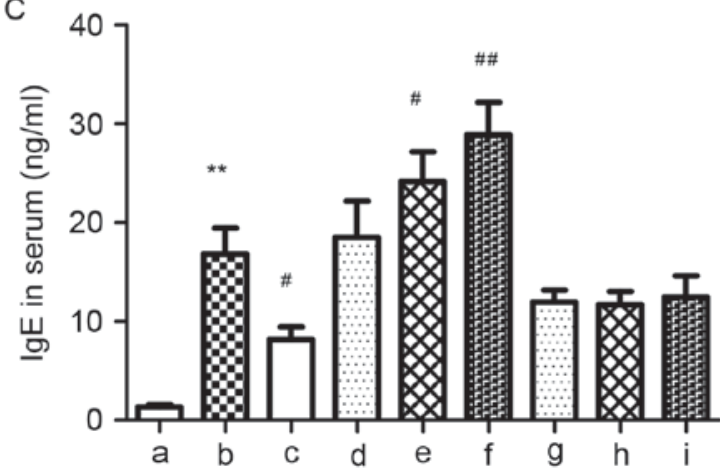

B \#\#

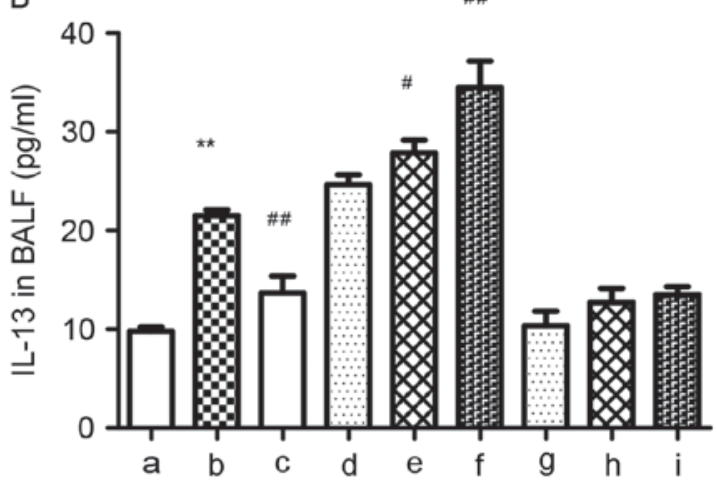

Figure 3. ELISA measurements. (A) IL-4 and (B) IL-13 levels in the BALF, and (C) total IgE in serum were measured by ELISA. Data are expressed as the mean \pm standard error ( $\mathrm{n}=6-8 /$ group). ${ }^{* *} \mathrm{P}<0.01$ vs. control group; ${ }^{*} \mathrm{P}<0.05$ and ${ }^{\# \#} \mathrm{P}<0.01$ vs. OVA group. a, control group; b, OVA group; c, OVA/DXM group; d, OVA/PM2.5 (10 $\mu \mathrm{g})$ group; e, OVA/PM2.5 (31.6 $\mu \mathrm{g})$ group; f, OVA/PM2.5 (100 $\mu \mathrm{g})$ group; g, OVA/DXM/PM2.5 (10 $\mu \mathrm{g})$ group; h, OVA/DXM/PM2.5 $(31.6 \mu \mathrm{g})$ group; i, OVA/DXM/PM2.5 (100 $\mu \mathrm{g})$ group. BALF, broncho-alveolar lavage fluid; IL, interleukin; OVA, ovalbumin; DXM, dexamethasone; IgE, immunoglobulin E.

A
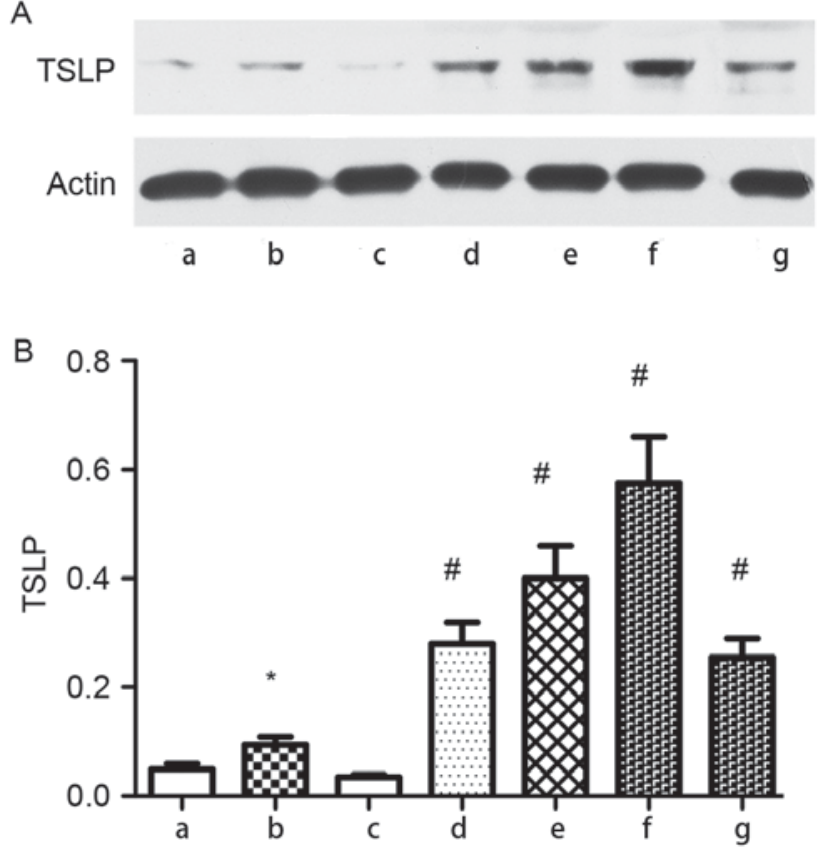

Figure 4. TSLP expression in the lungs of asthmatic mice. (A) Representative western blot images and (B) quantification of TSLP protein expression levels in lung tissue of mice. Actin served as an internal control. Data are expressed as the mean \pm standard error $\left(n=6-8 /\right.$ group). ${ }^{*} \mathrm{P}<0.05$ vs. control group; ${ }^{\#} \mathrm{P}<0.05$ vs. OVA group. a, control group; b, OVA group; c, OVA/DXM group; d, OVA/PM2.5 (10 $\mu \mathrm{g})$ group; e, OVA/PM2.5 (31.6 $\mu \mathrm{g})$ group; f, OVA/PM2.5 $(100 \mu \mathrm{g})$ group; g, OVA/DXM/PM2.5 (100 $\mu \mathrm{g})$ group. OVA, ovalbumin; DXM, dexamethasone; TSLP, thymic stromal lymphopoietin. with oxidative stress but also with many of the phenotypic changes associated with asthma. Furthermore, PM2.5 also includes various immunogenic substances, including fungal spores and pollen, which have been independently associated with exacerbations of asthma symptoms $(13,14)$. Exposure to PM2.5 can result in oxidative stress and lung function abnormalities including increased airflow obstruction and airway hyperresponsiveness, either alone or in combination with allergic sensitization $(8,15)$. Although the mechanisms by which exposure to PM2.5 exacerbates asthma remain unclear, the framework proposed by the UK Committee on the medical effects of air pollutants identified four main mechanisms: Oxidative stress and damage, inflammatory pathways, airway remodeling and immunological responses, and enhancement of respiratory sensitization to aeroallergens $(16,17)$.

In terms of the effects of PM2.5 on allergic airway inflammation, the present study demonstrated that compared with the OVA group, a significant increase in inflammatory cell infiltration was identified in the OVA/PM2.5 (31.6 and $100 \mu \mathrm{g}$ ) groups. These data demonstrated that exposure to PM2.5 results in aggravation of allergic airway inflammation and the infiltration of inflammatory cells including eosinophils, lymphocytes and neutrophils. Eosinophils are the most important inflammatory effector cells. They infiltrate and accumulate at the sites of allergic inflammation, where they release cytotoxic and inflammatory molecules and cause airway epithelial damage, which results in the manifestation of allergic asthma $(18,19)$. Furthermore, the present study revealed that compared with the OVA group, there were statistically significant changes in the 
levels of IL-13 and IL-4 in the OVA/PM2.5 (31.6 and $100 \mu \mathrm{g}$ ) groups. This indicated that exposure to PM2.5 can cause activation of the inflammatory cells, thereby promoting release of the IL- 4 and IL-13 cytokines. It is known that although the $\mathrm{T}$ cell-derived cytokines IL-4 and IL-13 have distinct functions, they are structurally similar and share a functional signaling receptor chain (the IL-4Ra chain) $(20,21)$. These mediators are critical in regulating certain inflammatory and immune responses. Various functions, including regulation of the expression of the eosinophil-activating molecules, promotion of $\operatorname{IgE}$ isotype switching, enhancement of the expression of major histocompatibility class II antigens on B cells, and regulation of the expression of pro-inflammatory cytokines and chemokines by monocytes, may be attributed to IL- 4 and IL-13 (22). Therefore, the underlying mechanism by which PM2.5 aggravates asthmatic airway inflammation may be associated with the upregulation of IL-4 and IL-13 expression.

The present study demonstrated that serum IgE levels were increased following $100 \mu \mathrm{g}$ PM2.5 administration. Therefore, the mechanism by which PM2.5 aggravates asthmatic airway inflammation may be associated with the expression of serum IgE. IgE is a trigger and mediator of type 2 inflammation. It acts as part of a protein network that includes its two principal receptors, FceRI (high-affinity Fc receptor for IgE) and CD23 (also known as FceRII), and the IgE-and-FceRI-binding protein $(23,24)$. FceRI is expressed by mast cells and basophils, in which its activation mediates cellular degranulation, eicosanoid production and cytokine production, whereas FceRII is expressed by B cells, in which it regulates IgE production and facilitates antigen processing and presentation (25). IgE can mediate the type I hypersensitivity reactions that contribute to the pathogenesis of allergic asthma. The levels of serum IgE in healthy humans are very low (50-200 ng per $\mathrm{ml}$ of blood) compared with other immunoglobulin isotypes (1-10 $\mathrm{mg}$ per $\mathrm{ml}$ of blood); similar relative values are also present in mice $(25,26)$. Additionally, compared with the OVA group, 31.6 and $100 \mu \mathrm{g}$ PM2.5 administration significantly altered these levels in mice; however, $10 \mu \mathrm{g}$ did not. Furthermore, the changes in the OVA/PM2.5 $(100 \mu \mathrm{g})$ group were greater. Therefore, the development of airway inflammation in the asthmatic mice may be closely associated with the dose of PM2.5. PM2.5 in the bronchi and alveoli following deposition promotes macrophages to release pro-inflammatory cytokines and causes oxidative damage of the airway epithelium $(27,28)$.

The percentage of neutrophils and the levels of IL-4/IL-13 and total $\mathrm{IgE}$ in the OVA/DXM/PM2.5 $(100 \mu \mathrm{g})$ group were significantly different from the OVA/DXM group. Furthermore, these results corresponded with TSLP protein expression levels, as assessed by western blotting. These data demonstrated that exposure to a high dose of PM2.5 $(100 \mu \mathrm{g})$ may inhibit the activity of the DXM-inducible glucocorticoid response element after OVA-sensitization and OVA-challenge. This result highlights a novel mechanism by which a high concentration of PM2.5 promotes glucocorticoid insensitivity. It is also clear that there is a need for improved understanding of the pathogenesis, which may lead to a greater range of treatment options for asthma. TSLP is now recognized as a protein released primarily from epithelial cells in response to proinflammatory stimuli. The activity of this protein drives the allergic inflammatory response in asthmatic mice. TSLP serves a major role in the allergen-induced airway response and persistent airway inflammation driven by Th2 cells $(29,30)$. Numerous mechanisms have been demonstrated. First, elevated levels of TSLP expression have been identified in the lungs of asthmatics (31). Second, TSLP is an epithelial cell (EC)-derived cytokine, and asthma develops at EC surfaces. Over the past few years, a role for TSLP in allergic inflammation has been demonstrated in both humans and mice $(32,33)$. The present study demonstrated that a high concentration of PM2.5 induces glucocorticoid insensitivity. In addition to the TSLP functions, reduced levels of HDAC2 also serve a critical role in glucocorticoid insensitivity.

As mentioned above, the aspirated doses of 10, 31.6 and $100 \mu \mathrm{g}$ PM2.5 in mice are considered to be equivalent to low, moderate and severe pollution. Exposure to concentrations of PM2.5 equivalent to moderate pollution and severe pollution has been linked to acute exacerbations of allergic airway inflammation in mice. In contrast, concentrations of PM2.5 equivalent to low pollution levels resulted in no significant effects $(6,34,35)$.

In conclusion, the results from the present study suggested the exacerbation of allergic airway inflammation in mice from exposure to PM2.5 are closely associated with increased infiltration of asthmatic airway inflammatory cells, upregulation of IL-4/IL-13 expression, elevated levels of serum IgE and damage to the airway epithelial cells and oxidative stress, following deposition of PM2.5 in the bronchi and alveoli. Concentrations of PM2.5 equivalent to moderate and severe pollution may cause acute exacerbations of allergic airway inflammation in mice. When the concentrations of PM2.5 were equivalent to low pollution, no significant effects were observed. It is necessary to further examine the specific mechanisms of these responses. The results of the present study serve as a basis for further study on the pathogenesis of disease, and implicate potential interventions to prevent the exacerbation of asthma.

\section{Acknowledgements}

This study was supported by the Six Talent Peaks project in Jiangsu Province (grant no. WSN-015).

\section{References}

1. Bateman ED, Hurd SS, Bames PJ, Bousquet J, Drazen JM, FitzGerald M, Gibson P, Ohta K, O'Byrne P, Pedersen SE, et al: Global strategy for asthma management and prevention: GINA executive summary. Eur Respir J 31: 143-178, 2008.

2. Fahy JV: Type 2 inflammation in asthma-present in most, absent in many. Nat Rev Immunol 15: 57-65, 2015.

3. Lambrecht BN and Hammad H: The immunology of asthma. Nat Immunol 16: 45-56, 2015.

4. Shadie AM, Herbert C and Kumar RK: Ambient particulate matter induces an exacerbation of airway inflammation in experimental asthma: Role of interleukin-33. Clin Exp Immunol 177: 491-499, 2014

5. Wang J, Ho SS, Cao J, Huang R, Zhou J, Zhao Y, Xu H, Liu S, Wang G, Shen Z and Han Y: Characteristics and major sources of carbonaceous aerosols in PM2.5 from Sanya, China. Sci Total Environ 530-531: 110-119, 2015.

6. Gavett SH, Haykal-Coates N, Highfill JW, Ledbetter AD, Chen LC, Cohen MD, Harkema JR, Wagner JG and Costa DL: World Trade Center fine particulate matter causes respiratory tract hyperresponsiveness in mice. Environ Health Perspect 111: 981-991, 2003. 
7. United States Environmental Protection Agency: Air quality index: A guide to air quality and your health. 2014. https://cfpub. epa.gov/airnow/index.cfm?action=aqi_brochure.index $\# \% 23$

NO_LINK_PROXY. Accessed February 2014.

8. Wagner JG, Morishita M, Keeler GJ and Harkema JR: Divergent effectsof urban particulate air pollution on allergic airway responses in experimental asthma: A comparison of field exposure studies. Environ Health 11: 45, 2012.

9. Duan W, Chan JH, Wong $\mathrm{CH}$, Leung BP and Wong WS: Anti-inflammatory effects of mitogen-activated protein kinasekinase inhibitor U0126 in an asthma mouse model. J Immunol 172: 7053-7059, 2004.

10. Yao J, Zhang YS, Feng GZ and Du Q: Chrysin inhibits human airway smooth muscle cells proliferation through the extracellular signal-regulated kinase 1/2 signaling pathway. Mol Med Rep 12: 7693-7698, 2015.

11. Mireille B, Zeina D, Ledoux F, Verdin A, Cazier F, Martin P, Hachimi A, Shirali P, Greige-Gerges H and Courcot D: Comparison between ultrafine and fine particulate matter collected in Lebanon: Chemical characterization, in vitro cytotoxic effects and metabolizing enzymes gene expression in human bronchial epithelial cells. Environ Pollut 205: 250-260, 2015.

12. Riva DR, Magalhães CB, Lopes AA, Lanças T, Mauad T, Malm O, Valença SS, Saldiva PH, Faffe DS and Zin WA: Low dose of fine particulate matter (PM2.5) can induce acute oxidative stress, inflammation and pulmonary impairment in healthy mice. Inhal Toxicol 23: 257-267, 2011.

13. Li MH, Fan LC, Mao B, Yang JW, Choi AM, Cao WJ and Xu JF Short term exposure to ambient fine particulate matter increases hospitalizations and mortality in COPD: A systematic review and meta-analysis. Chest 149: 447-458, 2016.

14. Stanek LW, Brown JS, Stanek J, Gift J and Costa DL: Air pollution toxicology-a brief review of the role of the science in shaping the current understanding of air pollution health risks. Toxicol Sci 120 (Suppl 1): S8-S27, 2011.

15. Tarlo SM and Lemiere C: Occupational asthma. N Engl J Med 370: 640-649, 2014

16. Gowers AM, Cullinan P, Ayres JG, Anderson HR, Strachan DP, Holgate ST, Mills IC and Maynard RL: Does outdoor air pollution induce new cases of asthma? Biological plausibility and evidence; A review. Respirology 17: 887-898, 2012.

17. Wong CK, Hu S, Leung KM, Dong J, He L, Chu YJ, Chu IM, Qiu HN, Liu KY and Lam CW: NOD-like receptors mediated activation of eosinophils interacting with bronchial epithelial cells: A link between innate immunity and allergic asthma. Cell Mol Immunol 10: 317-329, 2013.

18. Hogan SP, Rosenberg HF, Moqbel R, Phipps S, Foster PS, Lacy P, Kay AB and Rothenberg ME: Eosinophils: Biological properties and role in health and disease. Clin Exp Allergy 38: 709-750, 2008.

19. Lemière $C$, Ernst $P$, Olivenstein $R$, Yamauchi $Y$, Govindaraju $K$, Ludwig MS, Martin JG and Hamid Q: Airway inflammation assessed by invasive and noninvasive means in severe asthma: Eosinophilic and noneosinophilic phenotypes. J Allergy Clin Immunol 118: 1033-1039, 2006.
20. Wills-Karp M and Finkelman FD: Untangling the complex web of IL-4- and IL-13-mediated signaling pathways. Sci Signal 1: pe55, 2008

21. Omori-Miyake M, Yamashita M, Tsunemi Y, Kawashima M and Yagi J: In vitro assessment of IL-4- or IL-13-mediated changes in the structural components of keratinocytes in mice and humans. J Invest Dermatol 134: 1342-1350, 2014

22. David M, Ford D, Bertoglio J, Maizel AL and Pierre J: Induction of the IL-13 receptor alpha2-chain by IL-4 and IL-13 in human keratinocytes: Involvement of STAT6, ERK and p38 MAPK pathways. Oncogene 20: 6660-6668, 2001.

23. Gould HJ and Sutton BJ: IgE in allergy and asthma today. Nat Rev Immunol 8: 205-217, 2008.

24. Acharya M, Borland G, Edkins AL, Maclellan LM, Matheson J, Ozanne BW and Cushley W: CD23/FceRII: Molecular multi-tasking. Clin Exp Immunol 162: 12-23, 2010.

25. Wu LC and Zarrin AA: The production and regulation of IgE by the immune system. Nat Rev Immunol 14: 247-259, 2014

26. Dullaers M, De Bruyne R, Ramadani F, Gould HJ, Gevaert P and Lambrecht BN: The who, where, and when of IgE in allergic airway disease. J Allergy Clin Immunol 129: 635-645, 2012.

27. Chuang HC, Ho KF, Cao JJ, Chuang KJ, Ho SS, Feng PH, Tian L, Lee CH, Han YM, Lee CN and Cheng TJ: Effects of non-protein-type amino acids of fine particulate matter on E-cadherin and inflammatory responses in mice. Toxicol Lett 237: 174-180, 2015.

28. Martin S, Fernandez-Alanis E, Delfosse V,Evelson P, Yakisich JS, Saldiva PH and Tasat DR: Low doses of urban air particles from Buenos Aires promote oxidative stress and apoptosis in mice lungs. Inhal Toxicol 22: 1064-1071, 2010.

29. Gauvreau GM, O'Byrne PM, Boulet LP, Wang Y, Cockcroft D, Bigler J, FitzGerald JM, Boedigheimer M, Davis BE, Dias C, et al: Effects of an anti-TSLP antibody on allergen-induced asthmatic responses. N Engl J Med 370: 2102-2110, 2014.

30. Dahlén SE: TSLP in asthma-a new kid on the block? N Engl J Med 370: 2144-2145, 2014.

31. Soumelis V, Reche PA, Kanzler H, Yuan W, Edward G, Homey B, Gilliet M, Ho S, Antonenko S, Lauerma A, et al: Human epithelial cells trigger dendritic cell mediated allergic inflammation by producing TSLP. Nat Immunol 3: 673-680, 2002.

32. Zhang Y, Zhou X and Zhou B: DC-derived TSLP promotes Th2 polarization in LPS-primed allergic airway inflammation. Eur J Immunol 42: 1735-1743, 2012.

33. Han H, Xu W, Headley MB, Jessup HK, Lee KS, Omori M, Comeau MR, Marshak-Rothstein A and Ziegler SF: Thymic stromal lymphopoietin (TSLP)-mediated dermal inflammation aggravates experimental asthma. Mucosal Immunol 5: 342-351, 2012.

34. Gavett SH, Haykal-Coates N, Copeland LB, Heinrich J and Gilmour MI: Metal composition of ambient PM2.5 influences severity of allergic airways disease in mice. Environ Health Perspect 111: 1471-1477, 2003.

35. Zhang X, Zhong W, Meng Q, Lin Q, Fang C, Huang X, Li C, Huang Y and Tan J: Ambient PM2.5 exposure exacerbates severity of allergic asthma in previously sensitized mice. J Asthma 52: 785-794, 2015. 